\title{
Hadean protocrust reworking at the origin of the Archean Napier Complex (Antarctica)
}

\author{
M. Guitreau1*, M. Boyet ${ }^{1}$, J.-L. Paquette ${ }^{1}$, A. Gannoun', \\ Z. Konc ${ }^{1}$, M. Benbakkar ${ }^{1}$, K. Suchorski ${ }^{1}, J^{-}-M$. Hénot $^{1}$
}

Abstract

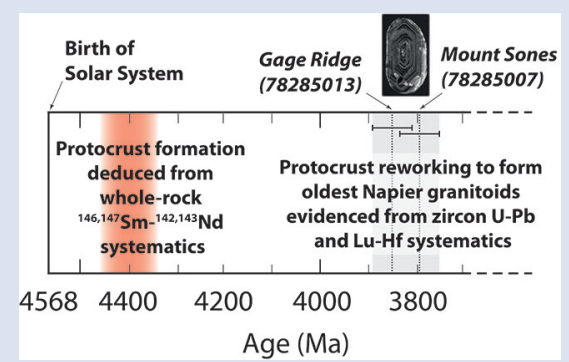

The origin of the first continents is still poorly constrained due to the great scarcity of $>3.7$ Ga rocks. The Napier Complex (East Antarctica) hosts such rocks but the extreme metamorphic conditions it experienced have compromised most isotopic systematics. Here we have studied Mount Sones and Gage Ridge orthogneisses from the Napier complex using microbeam (LA-MC-ICP-MS) U-Pb and Lu-Hf isotope measurements in zircon, together with ${ }^{146,147} \mathrm{Sm}-{ }^{143,142} \mathrm{Nd}$ isotope systematics in the corresponding whole rocks to uncover primary information about their origin. Our $\mathrm{U}-\mathrm{Pb}$ results reveal that these orthogneisses formed at $3794 \pm 40$ and $3857 \pm 39 \mathrm{Ma}$, respectively, by reworking of 4456-4356 Ma mafic protocrust, as testified to by ${ }^{176} \mathrm{Lu}-{ }^{176} \mathrm{Hf}$ and ${ }^{147,146} \mathrm{Sm}-{ }^{143,142} \mathrm{Nd}$ systematics. Other Eoarchean terranes in Greenland, Canada, and China also show involvement of Hadean crust(s) in their formation which suggests that protocrusts were massively reworked to form new continents around the Hadean-Eoarchean boundary. Such a mechanism would account for the absence of early-formed protocrust from the geological record despite recent models proposing rapid crustal growth in the Hadean ( $25 \%$ of present day volume or surface).

Received 28 June 2019 | Accepted 19 September 2019 | Published 8 November 2019

\section{Letter}

The small number of localities hosting $>3.7$ Ga rocks, together with the absence of Hadean rocks from the geological record, is a limitation for our understanding of the early evolution of the Earth and the origin of the first continents (e.g., Condie, 2007). The high metamorphic grade experienced by some of these Archean terranes further represents a challenge to uncover reliable information from their rocks and minerals. The Napier complex (East Antarctica) is one of the few Archean terranes that contain some of Earth's oldest rocks (Black et al., 1986; Fig. S-1). This complex recorded Meso- and Neoarchean metamorphism that reached extreme conditions corresponding to granulite facies at $2.5 \mathrm{Ga}\left(1050-1120^{\circ} \mathrm{C}\right.$ and $7-11 \mathrm{kbar}$; Table S-1) (Harley and Motoyoshi, 2000). Consequently, radiogenic isotope systematics (e.g., $\mathrm{Rb}-\mathrm{Sr}, \mathrm{Sm}-\mathrm{Nd}$ ) were severely disturbed in most samples (e.g., Black and McCulloch, 1987). Metamorphic events were recorded in zircon crystals that sometimes also preserved information about original crystallisation (Kelly and Harley, 2005). These grains show a greater complexity than commonly seen in ancient zircons (Williams et al., 1984; Black et al., 1986; Guitreau et al., 2012; Kusiak et al., 2013; Hiess and Bennett, 2016) and deconvoluting original igneous signatures from metamorphic overprints remains challenging. This is particularly well-illustrated by the great dispersion of data points in $\varepsilon_{\mathrm{Hf}}$ versus age space (Fig. S-2 and Table S-2). More importantly, the oldest signatures overlap enriched (negative $\varepsilon_{\mathrm{Hf}}$ values) and depleted (positive $\varepsilon_{\mathrm{Hf}}$ values) domains, hence, leaving open contrasting possibilities for the nature of the source to these ancient rocks. The analytical methods employed in previous studies do not allow these complexities to be understood, which justifies the present contribution.

Here we combine cathodoluminescence (CL) and back scattered electron (BSE) images with $\mathrm{U}-\mathrm{Pb}$ age profiles by laser ablation inductively coupled plasma mass spectrometry (LA-ICP-MS) in zircons from two Napier orthogneisses, following the procedure outlined in Guitreau et al. (2018). We also measured Lu-Hf isotope systematics by LA-MCICP-MS within the same zircon crystals. Finally, we analysed ${ }^{146,147} \mathrm{Sm}^{-143,142} \mathrm{Nd}$ isotope systematics in corresponding whole rock samples to constrain the early history of their source better. Information regarding analyses and results are provided in Methods (see Supplementary Information and Tables S-3 to S-11). The two studied samples are gran-ulitic orthogneisses labelled 78285007 (Mount Sones) and 78285013 (Gage Ridge). They are among the oldest rocks from this area (Black et al., 1986; Harley and Black, 1997). Mount Sones exhibits chemical composition identical to that of typical Archean tonalite-trondhjemite-granodiorite (TTG) suites (e.g., high $\mathrm{Na}_{2} \mathrm{O} / \mathrm{K}_{2} \mathrm{O}$, high $\mathrm{Sr} / \mathrm{Y}$, fractionated REE patterns; Moyen and Martin, 2012) with a normative composition intermediate between tonalite and trondhjemite (Black et al., 1986; Fig. S-3). Gage Ridge has a composition

1. Université Clermont Auvergne, IRD, CNRS, OPGC, Laboratoire Magmas et Volcans, UMR 6524, F-63000 Clermont-Ferrand, France

* Corresponding author (email: martin.guitreau@uca.fr) 

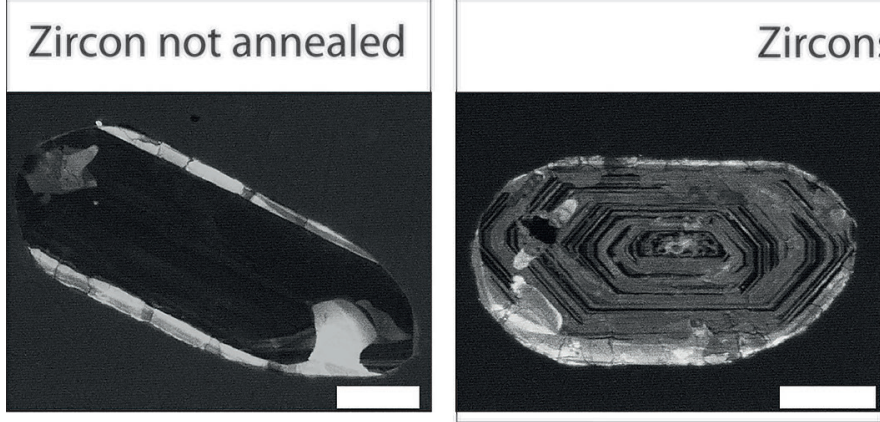

Group 1

\section{Zircons annealed $\left(850^{\circ} \mathrm{C}\right.$ for $\left.48 \mathrm{hr}\right)$}

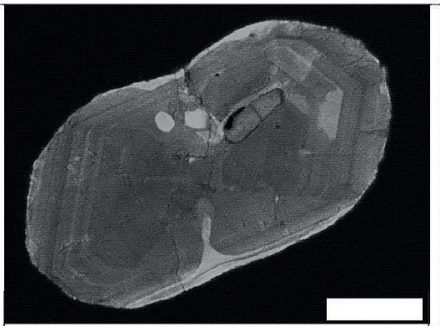

Group 2

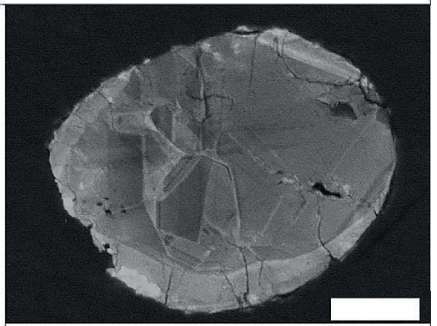

Group 3

Figure 1 Cathodoluminescence images of representative crystals from Napier zircon populations with details of textures with and without annealing. This figure illustrates the $\mathrm{CL}$ signal enhancing effect of zircon annealing which, in turn, allows three groups to be identified based on internal textures (see text for details). Thick white bars represent $50 \mu \mathrm{m}$.

closer to that of granite (Harleyand Black, 1997) despite a strongly fractionated REE pattern with a pronounced positive Eu anomaly suggesting that it is likely a cumulate from a TTG melt (Fig. S-3).

Napier zircon crystals have experienced a complex geological history which is difficult to decipher given their high $\mathrm{U}$ and Th concentrations that are responsible for the faint signals in CL images (e.g., Kusiak et al., 2013). These issues prevented internal textures to be examined properly in previous studies as shown in Figure 1 (see also Figs. S-4 to S-7). We performed annealing on a subset of zircon crystals $\left(850^{\circ} \mathrm{C}\right.$ for $48 \mathrm{hr}$ ) because this thermal process increases the intensity of the CL signal (Nasdala et al., 2002). Annealed zircons exhibit well-defined textures that allowed us to identify three groups (Fig. 1). The first group shows fine oscillatory zoning, with large contrasts between growth zones, that we interpreted as magmatic (Fig. 1). The second group is also interpreted as magmatic because it exhibits fine oscillatory zoning, with local sector zoning, but with very little contrast between growth zones (Fig. 1). The third group consists in irregular and/or chaotic textures that resemble metamorphic zircons (Fig. 1, Figs. S-4 to S-7; Corfu et al., 2003). The first and second groups are often surrounded by metamorphic overgrowths that, hence, belong to the third group (Figs. S-4 to S-7). All groups are present in Mount Sones, whereas only the first and third groups are represented in Gage Ridge.

In both samples, zircons from group 1 are characterised by large variations in ${ }^{207} \mathrm{~Pb} /{ }^{206} \mathrm{~Pb}$ ages, ranging from the oldest determined (3794 \pm 40 in Mount Sones and $3857 \pm 39$ Ma in Gage Ridge) down to about $2500 \mathrm{Ma}$, and broadly consistent initial ${ }^{176} \mathrm{Hf} /{ }^{177} \mathrm{Hf}$ around the least radiogenic values (0.2802-0.2804), except for a few data points in Gage Ridge (Fig. S-8, Table S-7). This translates into major positive correlations in $\varepsilon_{\mathrm{Hf}}$ versus age diagram with all $\varepsilon_{\mathrm{Hf}}$ being negative (Fig. 2). Group 2 zircons, which are only found in Mount Sones, form a coherent cluster with ${ }^{207} \mathrm{~Pb} / 206 \mathrm{~Pb}$ ages between $2700-2900 \mathrm{Ma}$ and initial ${ }^{176} \mathrm{Hf} /{ }^{177} \mathrm{Hf}$ among the most radiogenic (0.2806-0.2808; Fig. S-8, Table S-7) despite their corresponding initial $\varepsilon_{\mathrm{Hf}}$ values being all negative (Fig. 2). Group 3 zircons, contrary to group 1, show little variation in ${ }^{207} \mathrm{~Pb} /{ }^{206} \mathrm{~Pb}$ ages $(2400-2700 \mathrm{Ma})$ but large variations in initial ${ }^{176} \mathrm{Hf} /{ }^{177} \mathrm{Hf}$, and therefore $\varepsilon_{\mathrm{Hf}}$, that almost cover the entire range of measured values (Fig. 2). Contrary to the first two groups which exhibit Th/U values within the common igneous range (0.2-0.8; Fig. S-9; e.g., Kirkland et al., 2015), the third group in Mount Sones shows a great variability in Th/U (up to 2.9) in line with its metamor-phic origin in granulite facies (e.g., Vavra et al., 1999). Our new data comply very well with those already published (Guitreau et al., 2012; Hiess and Bennett, 2016), as shown in Figure S-2, and allow observed patterns to be properly deconvoluted and reliably interpreted.
The $\varepsilon_{\mathrm{Hf}}$-age pattern observed for group 1 is typical of ancient zircon populations (Fig. 2; e.g., Guitreau and BlichertToft, 2014) which experienced metamorphism that resulted in re-opening of the U-Pb system without influencing the Lu-Hf system signifi antly. Therefore, we interpret group 1 as the original igneous population. The second group is also igneous and probably represents melt percolation in Mount Sones, given its similarity in timing and Hf isotope composition to Dallwitz Nunatak orthogneiss which is located between Mount Sones and Gage Ridge (Figs. S-1 and S-10; Guitreau et al., 2012). Group 3 represents zircons that grew and/or recrystallised during long-lived Neoarchean metamorphism. Their formation likely involved in situ dissolution-reprecipitation of radiation-damaged zircons, as well as influx of radiogenic Hf from high Lu/Hf minerals (e.g., amphibole, biotite, plagioclase), thereby accounting for the large range of $\varepsilon_{\mathrm{Hf}}$ observed. The large discrepancies between Napier zircon and whole rock initial $\varepsilon_{\mathrm{Hf}}$ at $3.8 \mathrm{Ga}$ indicate that Lu-Hf isotope systematics were disturbed at the whole rock scale during later metamorphic events, most likely around 2.5 Ga (Fig. S-10).

Our oldest ages for Mount Sones and Gage Ridge orthogneisses determined at $3794 \pm 40$ and $3857 \pm 39 \mathrm{Ma}$, respectively, compares well with previous estimates of $3851 \pm 62$ Ma (Harley and Black, 1997; Kelly and Harley, 2005). The initial Hf isotope composition of group 1 zircons from Mount Sones and Gage Ridge are $0.280238 \pm 0.00004$ (2 s.d.; $\mathrm{n}=23$ ) and $0.280169 \pm 0.00007$ (2 s.d.; $\mathrm{n}=7$ ), respectively, which translates into initial $\varepsilon_{H f}$ of $-2.6 \pm 1.5$ and $-3.6 \pm 2.5$ for Mount Sones and Gage Ridge, respectively. Therefore, our results indicate that an enriched reservoir was tapped during the formation of the protoliths to the oldest orthogneiss of the Napier craton. Major and minor element concentrations for Mount Sones suggest its derivation from a mafic crust (Fig. S-3; Black et al., 1986). Gage Ridge exhibits a strong positive $\mathrm{Eu}$ anomaly that would indicate that it is a cumulate and, therefore, its composition no longer represents that of a liquid. Consequently, we cannot unambiguously estimate its source based on geochemistry.

Coupled ${ }^{147,146} \mathrm{Sm}_{-}{ }^{143,142} \mathrm{Nd}$ measurements provide additional constrains on the nature of this crust and the timing of its formation. Firstly, our new ${ }^{147} \mathrm{Sm}-{ }^{143} \mathrm{Nd}$ isotope data for Mount Sones are consistent with those published in Black and McCulloch (1987) (Fig. S-11) and give an $\varepsilon_{\mathrm{Nd}}$ of $-2.0 \pm 0.3$ at $3794 \mathrm{Ma}$, which compares well with the Hf isotope signature of group 1 zircons from this sample. Therefore, we suggest that Mount Sones exhibits a near-pristine Nd isotope signature in contrast to the arguably disturbed $\mathrm{Sm}-\mathrm{Nd}$ isotope systematics in Gage Ridge. Moreover, Napier samples exhibit negative $\mu^{142} \mathrm{Nd}$ anomalies of $-8.7 \pm 3.9$ for Mount Sones and $-12.1 \pm 6.2$ for Gage Ridge (Fig. 3, Table S-9) which indicates that they 


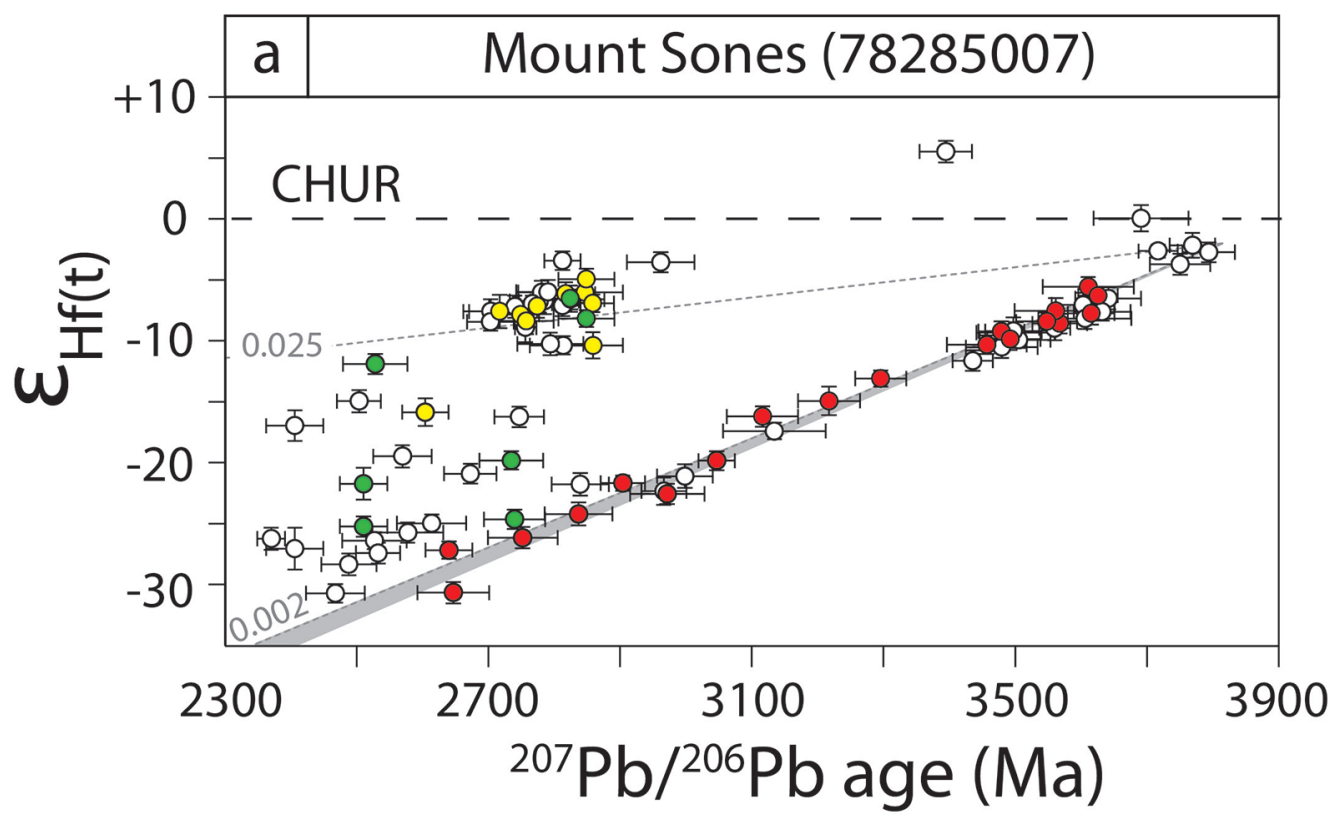

\begin{tabular}{|c|c|}
\hline$\circ \square$ Zircons $n$ & t annealed \\
\hline $\begin{array}{l}\text { G Group } 1 \\
\square \text { Group } 2 \\
\square \text { Group } 3\end{array}$ & $\begin{array}{l}\text { Annealed } \\
\text { zircons }\end{array}$ \\
\hline
\end{tabular}

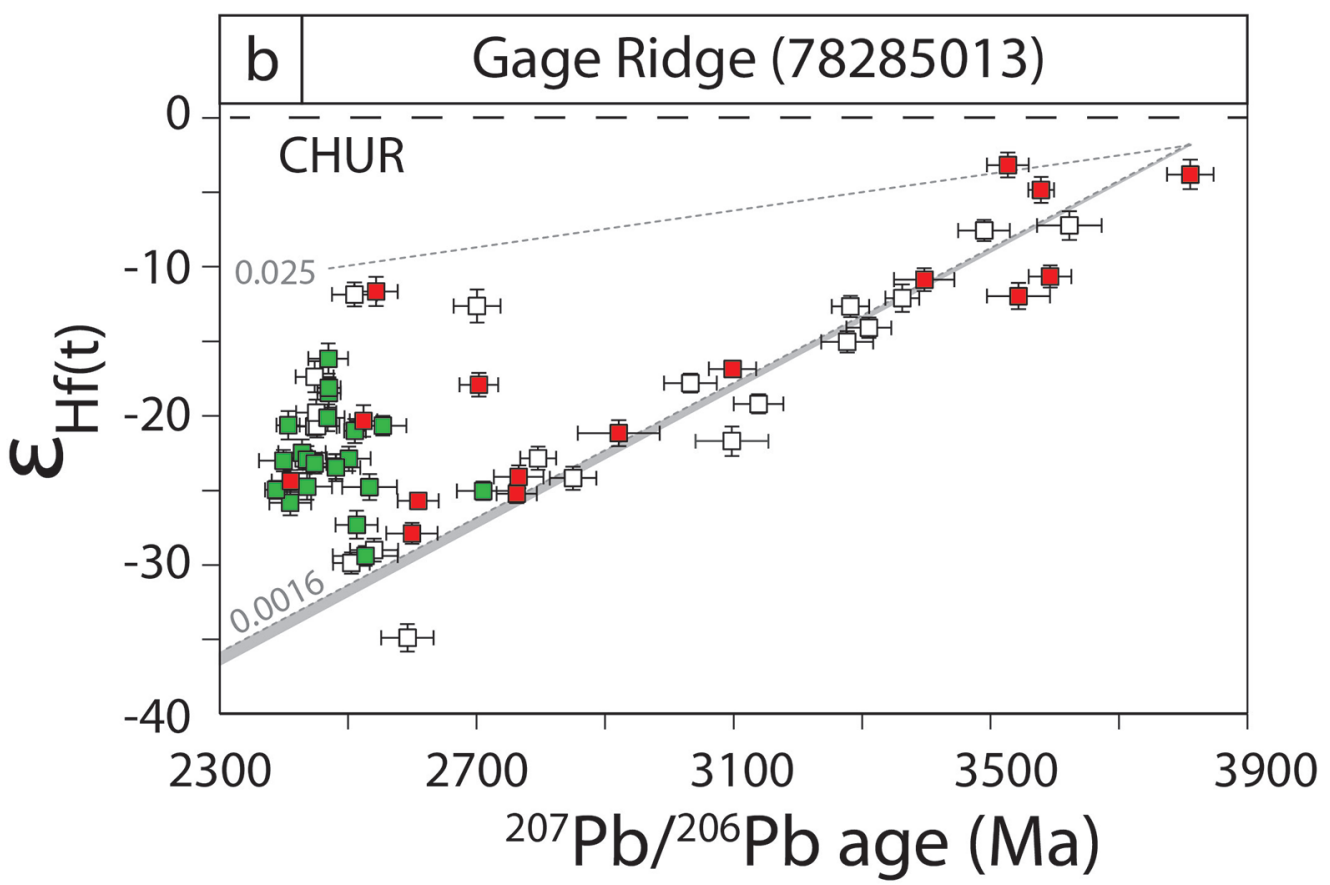

Figure $2 \varepsilon_{\mathrm{Hf}}$ versus ${ }^{207} \mathrm{~Pb} / 206 \mathrm{~Pb}$ age diagrams for Mount Sones and Gage Ridge zircons. Black dashed lines represent the time-evolution of a CHUR reservoir (lizuka et al., 2015) formed at $4568 \mathrm{Ma}$ (Bouvier and Wadhwa, 2010). Black dotted lines correspond to reservoirs that started with group 1 initial ${ }^{176} \mathrm{Hf} /{ }^{177} \mathrm{Hf}$ and evolved with ${ }^{176} \mathrm{Lu} /{ }^{177} \mathrm{Hf}$ ratios that are indicated on the left of the diagrams (e.g. 0.025). The values of 0.002 and 0.0016 correspond to ${ }^{176} \mathrm{Lu} /{ }^{177} \mathrm{Hf}$ measured in whole rock powders of Mount Sones and Gage Ridge orthogneisses, respectively. The grey fields encompass evolutions of Napier zircons based on highest and lowest ${ }^{176} \mathrm{Lu} /{ }^{177} \mathrm{Hf}$ measured in Mount Sones and Gage Ridge zircon populations. The general positive correlation of data for group 1 highlights typical artefacts of ancient $\mathrm{Pb}$ loss (e.g., Guitreau et al., 2012). Therefore, the original Hf isotope signatures of corresponding zircon populations are indicated by the oldest (and most concordant) crystals, which happen to be sub-chondritic for both samples. Data are fully consistent between annealed and not-annealed zircons, hence, demonstrating that annealing did not influence any of the measured systematics. 


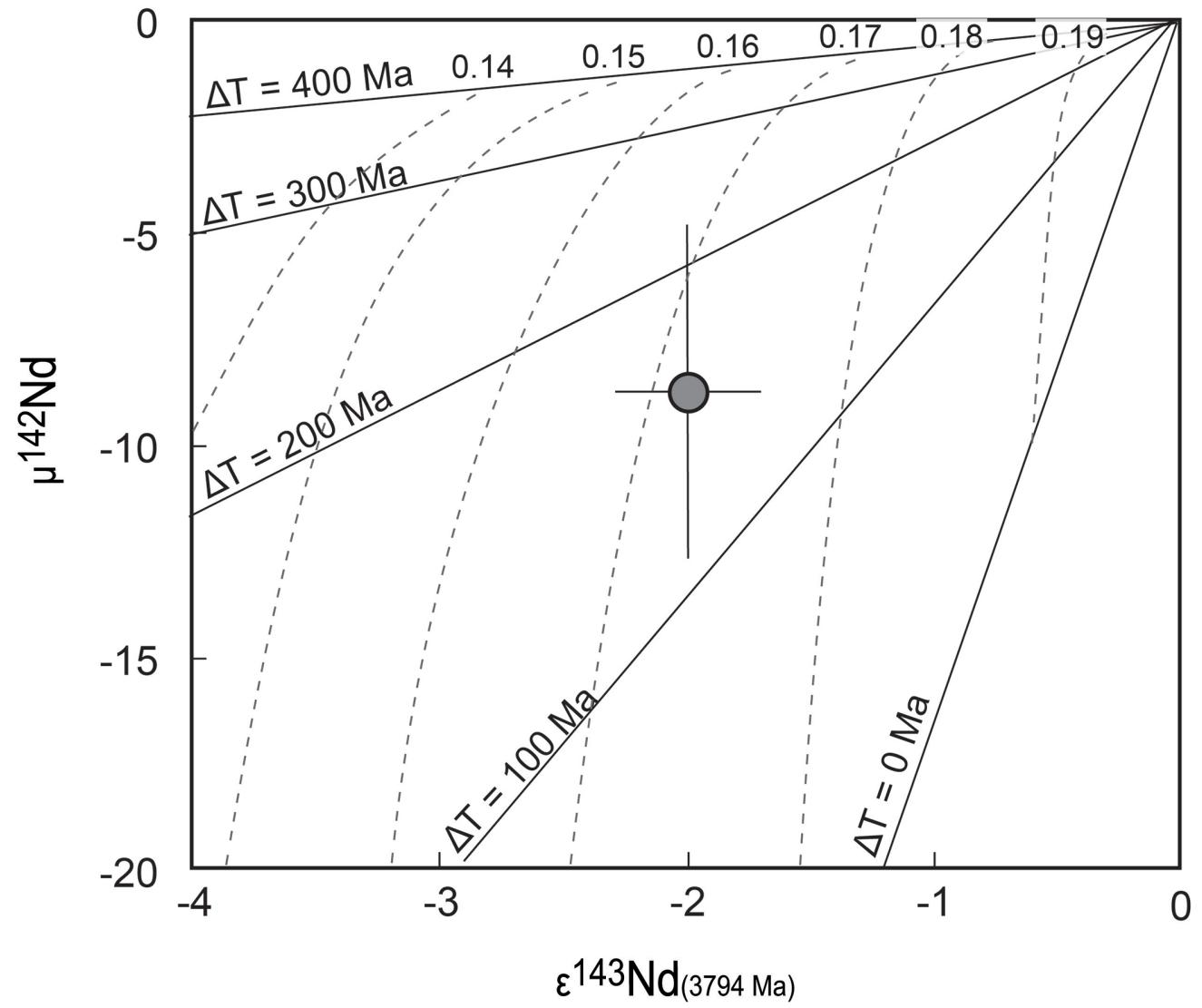

Figure 3 Coupled ${ }^{146} \mathrm{Sm}^{-142} \mathrm{Nd}$ and ${ }^{147} \mathrm{Sm}^{-143} \mathrm{Nd}$ plot showing the data obtained for Mount Sones orthogneiss (78285007) as well as the coupled evolution of $\mu^{142} \mathrm{Nd}$ and $\varepsilon^{143} \mathrm{Nd}$ signatures for lithologies with various $\mathrm{Sm} / \mathrm{Nd}$ ratios. Solid lines represent isochrons with respective ages indicated by $\Delta T$, which means time after $4568 \mathrm{Ma}$. Dashed curves correspond to the coupled evolution of $\mu^{142} \mathrm{Nd}$ and $\varepsilon^{143} \mathrm{Nd}$ signatures according to specific ${ }^{147} \mathrm{Sm} /{ }^{144} \mathrm{Nd}$ values that are indicated next to the curves (i.e. $\left.0.14-0.19\right)$. Mount Sones $\mu^{142} \mathrm{Nd}$ and $\varepsilon^{143} \mathrm{Nd}$ isotope signatures are compatible with a mafic source $\left({ }^{147} \mathrm{Sm} /{ }^{144} \mathrm{Nd}=0.17\right)$ that separated from a reservoir with a chondritic REE pattern $\sim 150$ Myr after Solar System formation (i.e. 4400 Myr ago). Here we assume that the initial ${ }^{142} \mathrm{Nd} /{ }^{144} \mathrm{Nd}$ ratio of the Earth is similar to that measured in the modern terrestrial mantle $\left(\mu^{142} \mathrm{Nd}=0\right)$, which is equivalent to the signature measured in enstatite chondrites from the EL sub-group (Boyet et al., 2018).

both tapped an enriched reservoir that formed while ${ }^{146} \mathrm{Sm}$ was still extant, hence, during the first 300 Myr of Solar System history. Coupled Sm-Nd isotope systematics in Mount Sones further indicate that the enriched reservoir (precursor) formed between 4456 and $4356 \mathrm{Ma}$ with a ${ }^{147} \mathrm{Sm} /{ }^{144} \mathrm{Nd}$ of $\sim 0.17$ (Fig. 3) which confirms i ts $\mathrm{m}$ afic na ture (e.g., $\mathrm{O}^{\prime}$ Neil an $\mathrm{d} \mathrm{Ca}$ rlson, 2017). Using a global compilation of coupled Lu-Hf and $\mathrm{Sm}-\mathrm{Nd}$ isotope systematics to estimate the equivalent ${ }^{176} \mathrm{Lu} /{ }^{177} \mathrm{Hf}$ to a ${ }^{147} \mathrm{Sm} /{ }^{144} \mathrm{Nd}$ of 0.17 (Albarède et al., 2000), we obtain a value of 0.025 which is typical of a mafic c rust. Two s tage C HUR Lu-Hf model ages for Group 1 zircons give ages of $4212 \pm 226$ Ma for Mount Sones and $4422 \pm 394$ Ma for Gage Ridge, which are consistent with combined ${ }^{147,146} \mathrm{Sm}-{ }^{143,142} \mathrm{Nd}$ isotope systematics (See Methods in Supplementary Information). Our new results on Mount Sones and Gage Ridge orthogneisses, therefore, demonstrate that a very old Hadean mafic protocrust was reworked during the formation of the Napier craton.

Our conclusion echoes similar scenarios that have been proposed for other Archean terranes worldwide such as the Itsaq Gneiss Complex (Greenland; Kamber et al., 2003; Kemp et al., 2019), the Acasta Gneiss Complex (Canada; e.g., Guitreau et al., 2014; Roth et al., 2014; Reimink et al., 2018), the Nuvvuagittuq Supracrustal Belt (Canada; e.g., O'Neil and Carlson, 2017; Caro et al., 2017), and the North China craton (Li et al., 2017). Therefore, we propose that Hadean proto-crusts (and proto-continents) were massively reworked at the Hadean-Eoarchean boundary in order to account for both the absence of Hadean crust in the present day and its little influence throughout the Archean (e.g., Guitreau et al., 2012; Roth et al., 2014; Kemp et al., 2015) despite recent models proposing that crustal growth was rapid in the Hadean and Eoarchean ( $25 \%$ of present-day volume or surface Belousova et al., 2010; Dhuime et al., 2012).

\section{Acknowledgements}

Chris Carson and Geoscience Australia are thanked for providing the Napier Complex samples. Anne-Magali Seydoux-Guillaume is thanked for discussions about zircon crystallography and imaging. MG acknowledges financial support from LabEx ClerVolc (ANR-10-LABX-0006), Région Auvergne, the European Regional Development Fund, and the French Agence Nationale de la Recherche (ANR) through the funded project Zircontinents (ANR-17-CE31-0021). MB acknowledges funding from the European Union's Horizon 2020 research and innovation programme under Grant Agreement $\mathrm{N}^{\circ} 682778$ and from the French Government Laboratory of Excellence initiative $n^{\circ} \mathrm{ANR}-10-\mathrm{LABX}-0006$. This is Laboratory of Excellence ClerVolc contribution number 376. Last but not least, we thank Ambre Luguet for efficient editorial handling and N. Alex Zirakparvar and Fernando Corfu for constructive reviews that helped improve the present manuscript.

Editor: Ambre Luguet 


\section{Additional Information}

Supplementary Information accompanies this letter at http:// www.geochemicalperspectivesletters.org/article1927.

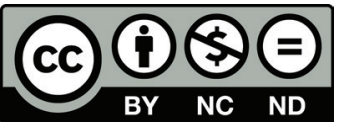

This work is distributed under the Creative Commons Attribution Non-Commercial No-Derivatives 4.0 License, which permits unrestricted distribution provided the original author and source are credited. The material may not be adapted (remixed, transformed or built upon) or used for commercial purposes without written permission from the author. Additional information is available at http://www.geochemicalperspectivesletters.org/ copyright-and-permissions.

Cite this letter as: Guitreau, M., Boyet, M., Paquette, J.-L., Gannoun, A., Konc, Z., Benbakkar, M., Suchorski, K., Hénot, J.-M. (2019) Hadean protocrust reworking at the origin of the Archean Napier Complex (Antarctica). Geochem. Persp. Let. 12, 7-11.

\section{References}

Albarède, F., Blichert-Toft, J., Vervoort, J.D., Gleason, J.D., Rosing, M. (2000) Hf-Nd isotope evidence for a transient dynamic regime in the early terrestrial mantle. Nature 404, 488-490.

Belousova, E.A., Kostitsyn, Y.A., Griffin, W.L., BegG, G.C., O’Reilly, S.Y., PEARSON, N.J. (2010) The growth of the continental crust: constraints from zircon Hf-isotope data. Lithos 119, 457-466.

BLACK, L.P., MCCulLOCH, M.T. (1987) Evidence for isotopic equilibration of Sm-Nd whole-rock systems in early Archaean crust of Enderby Land, Antarctica. Earth and Planetary Science Letters 82, 15-24.

Black, L.P., Williams, I.S., Compston, W. (1986) Four zircon ages from one rock - the history of a 3930 Ma-old granulite from Mount Sones, Enderby Land, Antarctica. Contributions to Mineralogy and Petrology 94, 427-437.

Bouvier, A., WADHWA, M. (2010) The age of the Solar System redefined by the oldest $\mathrm{Pb}-\mathrm{Pb}$ age of a meteoritic inclusion. Nature Geoscience 3, 637-641.

Boyet, M., Bouvier, A., Frossard, P., Hammouda, T., Garçon, M. GANNOUN, A. (2018) Enstatite chondrites EL3 as building blocks for the Earth: the debate over the ${ }^{146} \mathrm{Sm}_{-}{ }^{142} \mathrm{Nd}$ systematics. Earth and Planetary Science Letters 488, 68-78.

Caro, G., Morino, P., Mojzsis, S.J., Cates, N.L., Bleeker, W. (2017) Sluggish Hadean geodynamics: Evidence from coupled ${ }^{146,147} \mathrm{Sm}-{ }^{142,143} \mathrm{Nd}$ systematics in Eoarchean supracrustal rocks of the Inukjuak domain (Québec). Earth and Planetary Science Letters 457, 23-37.

Condie, K. (2007) The distribution of Paleoarchean crust. In: Van Kranen donk, M.J., Smithies, R.H., Bennett, V.C. (Eds.) Earth's Oldest Rocks. First Edition, Elsevier, Amsterdam, 9-18.

Corfu, F., Hanchar, J.M., Hoskin, P.W.O., Kinny, P. (2003) Atlas of zircon textures. Reviews in Mineralogy and Geochemistry 53, 469-500.

Dhuime, B., Hawkesworth, C.J., Cawood, P.A., Storey, C. (2012) A change in the geodynamics of continental growth 3 billion years ago. Science 335, 1334-1336.

GUITREAU, M., BLICHERT-TOFT, J. (2014) Implications of discordant U-Pb age on Hf isotope studies of detrital zircons. Chemical Geology 385, 17-25.

Guitreau, M., Blichert-Toft, J., Martin, H., Moizsis, S.J., Albarède, F. (2012) Hafnium isotope evidence from Archean granitic rocks for deep-mantle origin of continental crust. Earth and Planetary Science Letters 337, 211-223.

Guitreau, M., BlicherT-Toft, J., MOJZsis, S.J., Roth, A.S.G., BOURdON, B., CATES, N.L., BleEKER, W. (2014) Lu-Hf isotope systematics of the Hadean-Eoarchean Acasta Gneiss Complex (Northwest Territories, Canada). Geochimica et Cosmochimica Acta 135, 251-269.

Guitreau, M., Mora, N., Paquette, J.-L. (2018) Crystallization and disturbance histories of single zircon crystals from Hadean-Eoarchean Acasta gneisses examined by LA-ICP-MS U-Pb traverses. G-Cubed 19, 272-291.

HARLEY, S.L., BLACK, L.P. (1997) A revised Archaean chronology for the Napier Complex, Enderby Land, from SHRIMP ion-microprobe studies. Antarctic Science 9, 74-91.
Harley, S.L., Motoyoshi, Y. (2000) Al zoning in orthopyroxene in a sapphirine quartzite: evidence for $>1120^{\circ} \mathrm{C}$ UHT metamorphism in the Napier Complex, Antarctica, and implications for the entropy of sapphirine. Contributions to Mineralogy and Petrology 138, 293-307.

Hiess, J., BenNETT, V.C. (2016) Chondritic Lu-Hf in the early crust-mantle system as recorded by zircon populations from the oldest Eoarchean rocks of the Yilgarn Craton, West Australia and Enderby Land, Antarctica. Chemical Geology 427, 125-143.

Iizuka, T., Yamaguchi, T., HibiYa, Y., Amelin, Y. (2015) Meteorite zircon constraints on the bulk Lu-Hf isotope composition and early differentiation of the Earth. Proceedings of the National Academy of Science $112,5331-5336$

Kamber, B.S., Collerson, K.D., Moorbath, S., Whitehouse, M.J. (2003) Inheritance of early Archaean Pb-isotope variability from longlived Hadean protocrust. Contributions to Mineralogy and Petrology 145, $25-46$.

KeLLY, N.M., HARLEY, S.L. (2005) An integrated microtextural and chemical approach to zircon geochronology: refining the Archaean history of the Napier Complex east Antarctica. Contributions to Mineralogy and Petrology 149, 57-84.

Kemp, A.I.S., Hickman, A.H., KirkLAND, C.L., Vervoort, J.D. (2015) Hf isotopes in detrital and inherited zircons of the Pilbara Craton provide no evidence for Hadean continents. Precambrian Research 261, 112-126.

Kemp, A.I.S., Whitehouse, M.J., Vervoort, J.D. (2019) Deciphering the zircon Hf isotope systematics of Eoarchean gneisses from Greenland: Implications for ancient crust-mantle differentiation and $\mathrm{Pb}$ isotope controversies. Geochimica et Cosmochimica Acta 250, 76-97.

KirkLand, C.L., SMithies, R.H., TaYlor, R.J.M., Evans, N., McDonald, B. (2015) Zircon Th/U ratios in magmatic environs. Lithos 212-215, 397-414.

Kusiak, M.A., Whitehouse, M.J., Wilde, S.A., Nemchin, A.A., CLARK, C. (2013) Mobilization of radiogenic $\mathrm{Pb}$ in zircon revealed by ion imaging: implications for early Earth geochronology. Geology 41, 291-294

LI, C.-F., WANG, X.C., Wilde, S., Li, X.H., WANG, Y.F., LI, F. (2017) Differentiation of the early silicate Earth as recorded by ${ }^{142} \mathrm{Nd}-{ }^{143} \mathrm{Nd}$ in 3.8-3.0 Ga rocks from the Anshan Complex, North China craton. Precambrian Research 301, 86-101.

Moyen, J.-F., MARTin, H. (2012) Forty years of TTG research. Lithos 148, 312-336.

NASDAla, L., Lengauer, C.L., HANChar, J.M., Kronz, A., Wirth, R., Blanc, P., Kennedy, A.K., Seydoux-Guillaume, A.-M. (2002) Annealing radiation damage and the recovery of cathodoluminescence. Chemical Geology 191, 121-140.

O’Neil, J., CARLSON, R.W. (2017) Building Archean cratons from Hadean mafic crust. Science 355, 1199-1202.

Reimink, J.R., Chacko, T., Carlson, R.W., Shirey, S.B., LiU, J., Stern, R.A., Bauer, A.M., Pearson, D.G., Heaman, L.M. (2018) Petrogenesis and tectonics of the Acasta Gneiss $>$ Complex derived from integrated petrology and ${ }^{142} \mathrm{Nd}$ and ${ }^{182} \mathrm{~W}$ extinct nuclide-geochemistry. Earth and Planetary Science Letters 494, 12-22.

Roth, A.S.G., Bourdon, B., Mojzsis, S.J., Rudge, J.F., Guitreau, M., BLICHERT-TOFT, J. (2014) Combined ${ }^{147,146} \mathrm{Sm}-{ }^{143,142} \mathrm{Nd}$ constraints on the longevity and residence time of early terrestrial crust. G-Cubed $15,1-17$.

VAVRa, G., Schmid, R., Gebauer, D. (1999) Internal morphology, habit and U-Th-Pb microanalysis of amphibolite-to-granulite- facies zircons: geochronology of the Ivrea Zone (Southern Alps). Contributions to Mineralogy and Petrology 134, 380-404.

Williams, I.S., COMPSTON, W., Black, L.P., IReland, T.R., Foster, J.J. (1984) Unsupported radiogenic $\mathrm{Pb}$ in zircon: a cause of anomalously high $\mathrm{Pb}-\mathrm{Pb}, \mathrm{U}-\mathrm{Pb}$ and $\mathrm{Th}-\mathrm{Pb}$ ages. Contributions to Mineralogy and Petrology 88, 322-327. 